(c) American Dairy Science Association, 2002.

\title{
Effect of Replacing Corn Silage with Annual Ryegrass Silage on Nutrient Digestibility, Intake, and Milk Yield for Lactating Dairy Cows
}

\author{
J. K. Bernard, J. W. West, and D. S. Trammell \\ Department of Animal and Dairy Science, Coastal Plain Experiment Station \\ University of Georgia Tifton 31793-0748
}

\begin{abstract}
Twenty Holstein cows were used in an 8-wk randomized block design study to determine the effects of replacing corn silage with ryegrass silage on nutrient intake, apparent digestion, milk yield, and milk composition. The 8-wk trial consisted of a 2 -wk preliminary period followed by a 6 -wk collection period. Experimental diets were formulated to provide $55.5 \%$ of the total dry matter (DM) as forage. Ryegrass silage was substituted for $0,35,65$, and $100 \%$ of $\mathrm{DM}$ provided by corn silage. Dietary concentrations of neutral detergent fiber (NDF) and acid detergent fiber (ADF) increased as ryegrass silage replaced corn silage. Intake of DM and crude protein $(\mathrm{CP})$ was similar for all treatments, but intake of NDF and ADF increased linearly as ryegrass silage replaced corn silage. Apparent digestibility of DM declined linearly, whereas digestibility of CP increased linearly as ryegrass silage replaced corn silage. Apparent digestibility of NDF and $\mathrm{ADF}$ was highest for the diets in which ryegrass or corn silages provided all of the forage, resulting in a quadratic response. Dry matter intake was not different among treatments. Yield of milk, fat, and protein increased as ryegrass silage replaced corn silage. No differences were observed for body weight change, body condition score, and serum urea nitrogen concentration, but serum glucose concentration increased with increasing dietary proportion of ryegrass silage. These results indicate that substituting ryegrass silage for a portion or all of the corn silage in diets fed to lactating dairy cows can improve yield of milk and components.
\end{abstract}

(Key words: annual ryegrass silage, corn silage, nutrient digestibility, milk yield)

Abbreviation key: $\mathbf{C S}=$ corn silage, $\mathbf{E C M}=$ energycorrected milk, $\mathbf{R S}=$ annual ryegrass silage .

Received: January 9, 2002.

Accepted: February 2, 2002.

Corresponding author: J. K. Bernard; e-mail: jbernard@tifton. cpespeachnet.edu.

\section{INTRODUCTION}

Many dairy producers utilize winter annual forages such as annual ryegrass silage (RS) in addition to corn silage (CS) in their feeding program. Milk yield of cows consuming diets containing perennial RS was lower because of reduced intake compared with diets containing alfalfa silage (Hoffman et al., 1998). The potentially digestible NDF fraction of RS is greater than that of alfalfa (Hoffman et al., 1998), but the passage rate out of the rumen is lower than that for alfalfa (Waghorn et al., 1989). In contrast, annual RS has been shown to support similar DMI and milk yield as CS, forage sorghum silage (McCormick et al., 1990), or wheat silage (Ben-Ghedalia et al., 1995).

When harvested in a vegetative stage of maturity, RS typically contains large quantities of CP. Much of the protein in $\mathrm{RS}$ is readily degraded in the rumen (Van Vuuren et al., 1990). Including feeds that contain high concentrations of soluble carbohydrates improves nitrogen utilization by reducing ruminal ammonia and urinary $\mathrm{N}$ excretion (Van Vuuren et al., 1993). Feeding a blend of corn silage and grass or legume silage has been reported to increase yield of milk and components (Keys et al., 1984) and to improve nitrogen utilization and feed cost (Dhiman and Satter, 1997). No studies have been conducted to determine the potential effects of feeding blends of CS and RS. The objective of this study was to determine the effects of substituting RS for CS on intake and apparent digestibility of nutrients, milk yield, and milk composition.

\section{MATERIALS AND METHODS}

Corn (Agratech 787, Agra Tech Seeds, Inc., Ashburn GA) was planted on April 6, 1998 in a Tifton sandy loam soil at a seeding rate of approximately 69,135 plants per hectare. A commercial fertilizer was applied at the rate of $65 \mathrm{~kg}$ of N, $65 \mathrm{~kg} \mathrm{P}$, and $126 \mathrm{~kg}$ of K per ha immediately before planting. An additional $108 \mathrm{~kg}$ per ha of $\mathrm{N}$ was applied when the corn was approximately $60 \mathrm{~cm}$ in height. Irrigation was provided as needed to supplement natural rainfall. Corn was chopped on July 20, 1998 using a conventional pull- 
Table 1. Chemical composition of corn and annual ryegrass silage.

\begin{tabular}{lcc}
\hline & Corn silage & Ryegrass silage \\
\cline { 2 - 3 } DM & 42.5 & \\
\cline { 2 - 3 } & & \\
Ash & 4.28 & 60.0 \\
CP & 7.97 & 10.18 \\
NDF & 40.15 & 9.95 \\
ADF & 31.28 & 55.55 \\
IVTDMD & 66.97 & 31.28 \\
Lactate & 10.04 & 72.74 \\
Acetate & 1.50 & 4.61 \\
Propionate & 0.02 & 0.57 \\
Butyrate & 0.07 & 0.05 \\
\hline
\end{tabular}

${ }^{1}$ In vitro true $\mathrm{DM}$ digestibility.

type chopper and stored in a concrete stave silo. Annual ryegrass (Gulf) was planted at the rate of $50.4 \mathrm{~kg}$ per ha in Tifton sandy loam soil on October 23, 1998. Fertilizer was applied at the rate of $54 \mathrm{~kg}$ of $\mathrm{N}, 13 \mathrm{~kg}$ of $\mathrm{P}$, and $27 \mathrm{~kg}$ of $\mathrm{K}$ per ha immediately before planting. An additional $57 \mathrm{~kg}$ per ha of $\mathrm{N}$ was applied on February 25, 1999. Ryegrass was mown on April 2, 1999 and allowed to wilt to approximately $40 \% \mathrm{DM}$ before being chopped and stored in a plastic bag.

Twenty Holstein cows (309 \pm 86 DIM, $28.6 \pm 7.1 \mathrm{~kg} /$ $\mathrm{d}$ milk, $4.7 \pm 0.9 \%$ fat, $3.3 \pm 0.2 \%$ protein, and $661 \pm 60$ $\mathrm{kg} \mathrm{BW}$ ) were used in an 8-wk randomized block design study. Protocols for this trial were approved by the University of Georgia Institute of Animal Care and Use Committee. During a 2-wk pretrial period, cows were fed a corn silage and alfalfa hay-based ration containing 19.4\% CP, 20.7\% ADF, and 33.6\% NDF (DM basis). Rations were offered individually once daily for ad libitum consumption behind Calan doors (American Calan, Inc., Northwood, NH). At the end of the preliminary period, cows were blocked by energy-corrected milk (ECM) yield and assigned randomly to one of four experimental diets.

Experimental diets contained $55.5 \%$ of the total DM as forage (Table 2) and were fed once daily as a TMR. Ryegrass silage was substituted for $0,35,65$, and $100 \%$ of the CS DM in the experimental diets. Because RS was drier than the CS, water was added to diets containing RS to maintain 55\% DM. During the 6-wk collection period, the amount of TMR offered and orts were recorded daily. Samples of ingredients, diets, and orts were collected $4 \mathrm{~d}$ each wk, and DM content was determined by drying in a forced-air oven at $55^{\circ} \mathrm{C}$ for $48 \mathrm{~h}$. Distribution of particle size for each diet was determined each week using the Penn State particle separator (Heinrichs, 1996).

Ingredient, diet, and ort samples were composited by week and ground to pass through a 1-mm screen using a Wiley mill (Arthur H. Thomas, Philadelphia, PA).
Composite samples were analyzed for DM, CP, ash (AOAC, 1990) ADF, and NDF (Van Soest et al., 1991), and indigestible ADF (Cochran et al., 1986). The in vitro DM true digestibility of the forages was determined according to methods of Goering and Van Soest (1970). Samples of corn silage were analyzed for lactic acid and VFA concentrations (Williams et al., 1995).

Milk yield was recorded electronically at each milking (Alfa Laval Agri., Inc., Kansas City, MO). Milk samples were collected from two consecutive milkings each week and shipped to the Southeast Dairy Laboratory (McDonough, GA) for analysis of fat and protein concentrations using a Foss 4000 equipped with an A filter (Foss North America, Eden Prairie, MN).

Whole blood samples were collected $4 \mathrm{~h}$ after feeding by jugular venipuncture during wk 2 of the pretrial period and during wk 3 and 6 of the experimental period. Tubes were allowed to clot, and serum was harvested by centrifugation. Concentrations of urea nitrogen and glucose were measured using a Bodhringer Mannheim/Hitachi 912 automated chemistry analyzer (Roche Laboratory Systems, Indianapolis, IN).

Fecal grab samples were collected the last $3 \mathrm{~d}$ of wk 6 at 12 -h intervals. Sampling time was advanced by 4 $\mathrm{h}$ each day. Samples were dried in a forced-air oven at $55^{\circ} \mathrm{C}$, ground to pass through a $1-\mathrm{mm}$ screen, and composited by cow. Fecal samples were analyzed for $\mathrm{DM}$, ash, $\mathrm{CP}, \mathrm{ADF}, \mathrm{NDF}$ and indigestible ADF. Indigestible $\mathrm{ADF}$ was used as an internal marker to determine apparent digestibility of nutrients (Cochran et al., 1986). Intake data from wk 6 were used to calculate digestibility coefficients.

Cows were weighed on two consecutive days at the end of the preliminary period and wk 6 of the experimental period. BCS (Edmonson et al., 1989) were assigned by two independent evaluators at the end of the preliminary period and during wk 6 of the experimental period.

Analyses of covariance of production data, which included repeated measures, were conducted using MIXED procedures of SAS (1989). Sums of squares were partitioned to covariate, DIM at the beginning of the study, block, treatment, week, and week x treatment. Pretrial variables were used as covariates in each of the respective models. Cow within treatment was included as a random variable, and week was considered a repeated measure. Linear, quadratic, and cubic contrast statements were included in the model to test the effect of increasing amounts of RS. Analyses of variance for nutrient intake, apparent digestibility coefficients, BW, and BCS data were conducted using GLM procedures of SAS (1989). Sums of squares were partitioned to block and treatment. Linear, quadratic, and cubic 
Table 2. Ingredient and chemical composition and particle size distribution of experimental diets containing corn silage (CS) and annual ryegrass silage (RS).

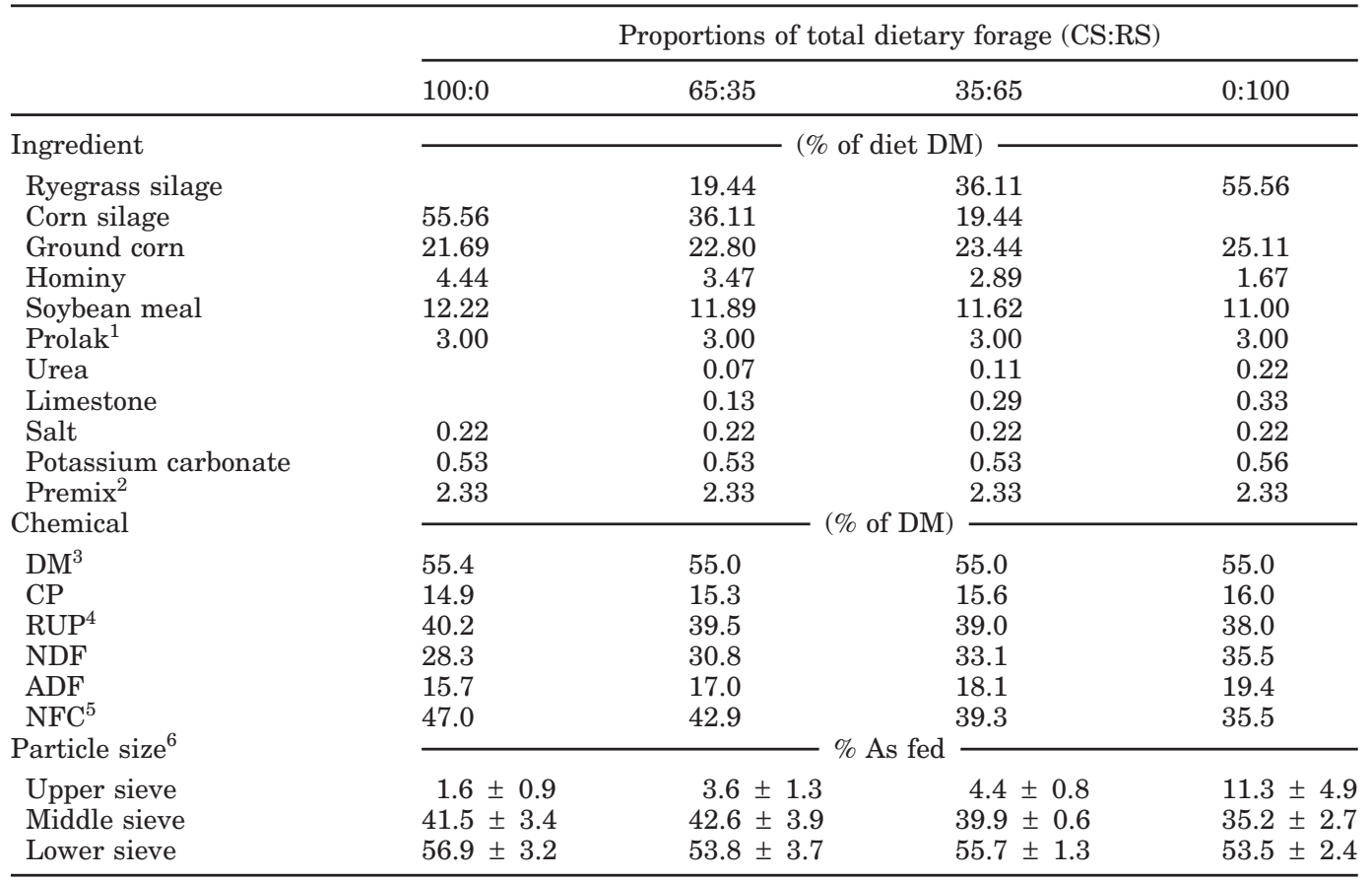

${ }^{1}$ Marine-animal blend (H. J. Baker \& Bros., Inc., Stamford, CT).

${ }^{2}$ Premix contained (DM basis) $99.07 \%$ ash; $14.27 \% \mathrm{Ca} ; 5.42 \% \mathrm{P} ; 4.96 \% \mathrm{Mg} ; 0.05 \% \mathrm{~K} ; 10.67 \% \mathrm{Na} ; 2.98 \%$ $\mathrm{Cl} ; 0.37 \% \mathrm{~S} ; 11 \mathrm{ppm}$ of Co; $577 \mathrm{ppm}$ of Cu; 4,858 ppm of Fe; $51 \mathrm{ppm}$ of I; 1,806 ppm of Mn; $13 \mathrm{ppm}$ of Se; $1,694 \mathrm{ppm}$ of Zn; 115,240 IU/kg of vitamin A; 46,100 IU/kg of vitamin D; and $576 \mathrm{IU} / \mathrm{kg}$ of vitamin E.

${ }^{3}$ Water was added to diets containing ryegrass silage to maintain $55 \% \mathrm{DM}$.

${ }^{4}$ Calculate using NRC (1989) values.

${ }^{5}$ Nonfibrous carbohydrate content calculated as $100-(\mathrm{CP}+\mathrm{NDF}+\mathrm{fat}+\mathrm{ash})$.

${ }^{6}$ Distribution determined according to Heinrichs, 1996.

contrasts were included in the model to test the effect of replacing CS with RS.

\section{RESULTS AND DISCUSSION}

The nutrient content of CS and RS is presented in Table 1. The DM content of both silages was higher than desired; however, concentration of fermentation end products was within normal ranges, and silages were readily consumed. Concentrations of $\mathrm{CP}$ in RS were lower than expected due to the dry growing conditions. The NDF and ADF content and in vitro true DM digestibility were higher for RS than CS. The chemical composition of the experimental diets is presented in Table 2. Concentrations of CP, NDF, and ADF in experimental diets tended to increase as RS replaced CS. Diets were formulated to contain similar concentrations of CP, but the CS actually contained lower concentrations of CP than expected based on preliminary analysis. The higher fiber content of the diets containing RS was because of the higher fiber content of RS compared with CS. The $100 \% \mathrm{RS}$ diet had a higher proportion of particles on the upper sieve, whereas the $100 \%$ CS diet had the lowest. Proportions of particles in the lower sieve were similar for all diets and were in the recommended range (Heinrichs, 1996).

Nutrient intake and apparent digestibility of diets during wk 6 are presented in Table 3. Intake of DM and CP were similar among diets, but intake of NDF and ADF increased linearly $(P<0.05)$ as RS replaced $\mathrm{CS}$, because of the higher dietary fiber concentrations of RS diets. Apparent digestibility of DM decreased linearly $(P<0.05)$, whereas CP digestibility increased linearly $(P<0.05)$ as RS replaced CS. A quadratic response was observed for apparent digestibility of NDF $(P<0.05)$ and $\mathrm{ADF}(P<0.01)$ and digestibility was greatest when all of the dietary forage was provided by either RS or CS instead of a blend of CS and RS.

Montgomery et al. (1976) reported lower CP digestibility for diets based on CS compared with those based on a blend of CS and alfalfa hay or low-moisture alfalfa silage. This decrease may be partially due to corn grain from the corn silage that passes through the reticulorumen to the lower tract without being digested. Nitro- 
Table 3. Nutrient intake and apparent digestibility of dairy cows fed diets containing different proportions of annual ryegrass and corn silage.

\begin{tabular}{|c|c|c|c|c|c|c|}
\hline & \multicolumn{4}{|c|}{ Proportions of total dietary forage (CS:RS) } & \multirow[b]{2}{*}{$\mathrm{SE}$} & \multirow[b]{2}{*}{ Contrast $^{1}$} \\
\hline & $100: 0$ & $65: 35$ & $35: 65$ & $0: 100$ & & \\
\hline \multicolumn{7}{|c|}{ Intake, kg/d } \\
\hline $\mathrm{DM}$ & 19.3 & 20.1 & 19.6 & 21.5 & 1.8 & NS \\
\hline $\mathrm{CP}$ & 3.2 & 3.4 & 3.3 & 3.6 & 0.3 & NS \\
\hline $\mathrm{NDF}$ & 5.5 & 6.2 & 6.5 & 7.7 & 0.6 & $\mathrm{~L}^{*}$ \\
\hline $\mathrm{ADF}$ & 3.0 & 3.4 & 3.5 & 4.1 & 0.3 & $\mathrm{~L}^{*}$ \\
\hline \multicolumn{7}{|c|}{ Apparent digestibility, \% } \\
\hline DM & 67.8 & 64.0 & 61.1 & 62.7 & 1.7 & $\mathrm{~L}^{*}$ \\
\hline $\mathrm{CP}$ & 62.6 & 62.3 & 64.8 & 67.7 & 1.7 & $\mathrm{~L}^{*}$ \\
\hline $\mathrm{NDF}$ & 54.4 & 50.1 & 49.3 & 54.6 & 2.0 & $\mathrm{Q}^{*}$ \\
\hline $\mathrm{ADF}$ & 52.7 & 47.0 & 44.0 & 54.0 & 2.7 & $Q^{* *}$ \\
\hline
\end{tabular}

${ }^{1}$ Linear (L) and quadric (Q) contrast.

$* P<0.05$.

$* * P<0.01$

gen from this grain would increase fecal $\mathrm{N}$ secretion, decreasing the apparent digestibility of CP. Joanning et al. (1981) suggested that reduced starch digestibility accounts for approximately one-half of the depression in the digestibility of CS. Lower starch availability would reduce the amount of energy available for synthesis of microbial protein in the reticulo-rumen, lowering $\mathrm{CP}$ digestibility and production potential.

The lower apparent digestibility of NDF and ADF observed for diets containing both CS and RS may be due in part to negative associative effects (Byers et al., 1975). Depressions in the apparent digestibility of DM of 4.8 and $6.2 \%$ for diets containing 33 or $66 \%$ corn were reported (Byers et al., 1975), which is similar to the depression in fiber digestibility in the current trial. Cellulolytic microorganisms utilize NH3 as their primary $\mathrm{N}$ source, which may be limited when rapidly fermentable carbohydrates are fed (Polan et al., 1976, Wohlt et al., 1978), thus reducing cellulose digestion (Stern et al., 1978). De Visser et al. (1998) observed a decrease in both the rate and extent of NDF digestibility in diets based primarily on grass silage in the presence of supplemental rumen degradable starch. As RS replaced CS, more ground corn was included in the diet. It is possible that the higher concentrations of rapidly fermentable carbohydrate present in the diets containing both CS and RS may have reduced the activity of cellulolytic microorganisms or that $\mathrm{NH}_{3}$ was limiting in these diets.

No difference was observed for DMI, which averaged $19.7 \mathrm{~kg} / \mathrm{d}$ or $3.0 \%$ of BW over the 6 -wk trial (Table 4 ). Milk yield increased linearly $(P<0.01)$ with increasing proportions of RS. Although DMI was not significantly different among treatments, intake of DM was numerically higher for the diets containing 65 and $100 \%$ RS, which explains part but not all of the milk yield response to increasing RS. Montgomery et al. (1976) re- ported lower DMI and milk yield for cows fed diets based on CS compared with that of cows fed blend of CS and alfalfa hay or low-moisture silage. Colenbrander et al. (1986) reported lower DMI as a percentage of BW for cows fed CS compared with either alfalfa silage or a blend of CS and alfalfa silage, but milk yield was similar for all treatments. These results are in contrast to those reported by McCormick et al. (1990), in which DMI and milk yield was similar for cows fed either CS or RS. Digestibility of DM was similar for CS and RS, but digestibility of CP and ADF was higher for RS than CS in their study. The chemical composition of diets fed by McCormick et al. (1990) was not reported, so it is not possible to compare diets to determine the reason for the difference in response. The in vitro true DM digestibility of CS was six units lower than RS in our trial, which may account for some of the difference in response.

A cubic response $(P<0.05)$ was observed for milk fat percentage, which was greater for the 35 and $100 \% \mathrm{RS}$ diets compared with the 0 and $65 \%$ RS diets (Table 4). No difference was observed among treatments for milk protein concentrations, but yields of fat, protein, and ECM increased linearly $(P<0.01)$ as the proportion of RS increased. Diets based primarily on corn silage often cause lower milk fat percentage due to inadequate effective fiber concentrations, but no inversions of milk fat and protein content were observed. Milk fat percentage typically increases when additional fiber is added to CS-based diets. The reason for the lower milk fat percentage observed for the diet containing $65 \% \mathrm{RS}$ is not apparent, but ADF digestibility was numerically lowest for this diet.

The initial BW and BCS of cows did not differ among treatments and averaged $661 \pm 60 \mathrm{~kg}$ and $3.36 \pm 0.71$, respectively, at the end of the preliminary period. No differences were observed in BW change $(-6.8 \mathrm{~kg})$ or 
Table 4. Dry matter intake, milk yield and composition and blood metabolites of dairy cows fed different proportions of annual ryegrass and corn silage.

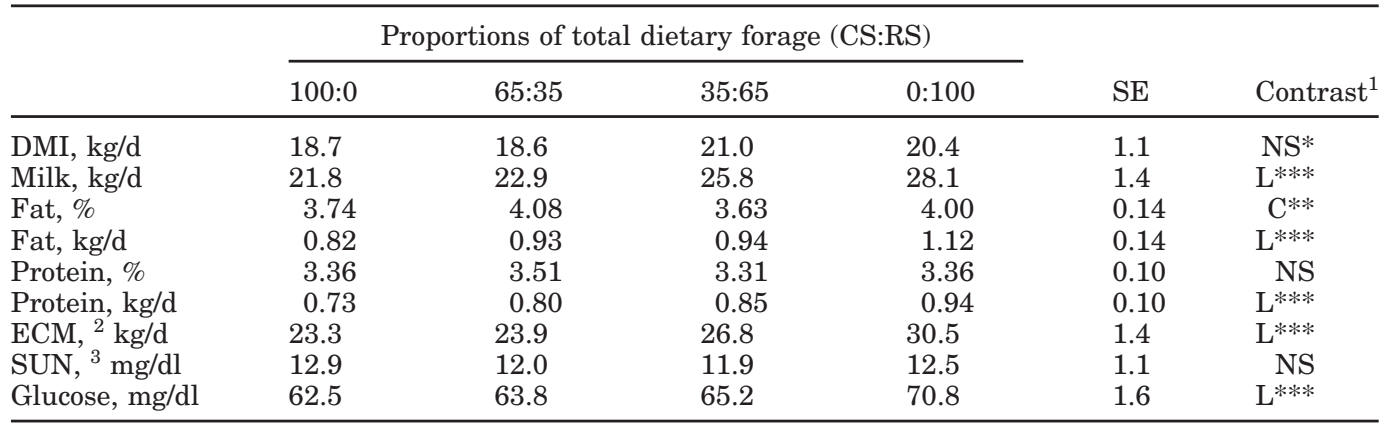

${ }^{1}$ Linear (L) and cubic (C) contrast.

${ }^{2}$ Energy-corrected milk.

${ }^{3}$ Serum urea nitrogen.

$* P>0.10$.

$* * P<0.05$.

$* * * P<0.01$.

BCS (+0.01) among treatments during the 6-wk experimental period. Serum concentrations of urea nitrogen were not different among treatments, but serum glucose concentrations increased linearly $(P<0.01)$ with increasing proportions of RS (Table 4). The increase in serum glucose concentrations may be related to lower digestion of starch digestion from grain in the CS compared with the ground corn included in the diet as the proportion of RS increased, which is consistent with the observed increases in yield of milk and protein.

\section{CONCLUSIONS}

Results of this trial indicate that substitution of RS for CS can improve yield of milk and components of lactating dairy cows. The increase in milk yield observed when substituting RS for CS can partially be explained by the slightly higher intake of DM as the proportion of RS in the diet increased. Fiber intake increased as RS was substituted for CS, which presumably improved ruminal starch digestion to provide additional energy and microbial protein to support the observed increased yield of milk and components based on the results of previous research. Additional research is needed to determine the effects on ruminal digestion as RS is substituted for CS.

\section{ACKNOWLEDGMENTS}

The authors thank the farm crew for assistance in production and harvest of silages, Wesley Godbee for his help with animal care, and Melissa Tawzer, Roger Gates, Jeff Dillard, Pat Smith, and Anita Merrill for their assistance in laboratory analysis.

\section{REFERENCES}

Association of Official Analytical Chemists International. 1990. Official Methods of Analysis. Vol. I. 15th ed. AOAC, Arlington, VA.

Ben-Ghedalia, D., A. Halevi, and J. Miron. 1995. Digestibility by dairy cows of monosaccharide components in diets containing wheat or ryegrass silages. J. Dairy Sci. 78:134-140.

Byers, F. M., J. K. Matsushima, and D. E. Johnson. 1975. The significance of associative effects of feeds on corn silage and corn grain energy values. Pages 18-21 in Colorado State Univ. Exp. Stn. Bull. No. 949, Ft. Collins, CO.

Cochran, R. C., D. C. Adams, J. D. Wallace, and M. L. Galyean. 1986. Predicting digestibility of different diets with internal markers: Evaluation of four potential markers. J. Anim. Sci. 63:1476-1483.

Colenbrander, V. F., D. L. Hill, M. L. Eastridge, and D. R. Mertens. 1986. Formulating dairy rations with neutral detergent fiber. 1. Effect of silage source. J. Dairy Sci. 69:2718-2722.

De Visser, H., A. Klop, C. J. Van Der Koelen, and A. M. Van Vuuren. 1998. Starch supplementation of grass harvested at two stages of maturity prior to ensiling: Intake, digestion and degradability by dairy cows. J. Dairy Sci. 81:2221-2227.

Dhiman, T. R., and L. D. Satter. 1997. Yield response of dairy cows fed different proportions of alfalfa silage and corn silage. J. Dairy Sci. 80:2069-2082.

Edmonson, A. J., I. J. Lean, L. D. Weaver, T. Farver, and F. Webster. 1989. A body condition scoring chart for Holstein dairy cows. J. Dairy Sci. 72:68-78.

Goering, H. K., and P. J. Van Soest. 1970. Forage Fiber Analyses (Apparatus, Reagents, Procedures, and Some Applications) Agric. Handbook No. 379. ARS-USDA, Washington, DC.

Heinrichs, J. 1996. Evaluating particle size of forages and TMRs using the Penn State particle size separator. DAS 96-20. Pennsylvania State Univ. Coll. Agric. Sci.

Hoffman, P. C., D. C. Combs, and M. D. Casler. 1998. Performance of lactating dairy cows fed alfalfa silage or perennial ryegrass silage. J. Dairy Sci. 81:162-168.

Joanning, S. W., D. F. Johnson, and B. P. Barry. 1981. Nutrient digestibility depressions in corn silage-corn grain mixtures fed to steers. J. Anim. Sci. 53:1095-1103.

Keys, J. E., R. E. Pearson, and R. H. Miller. 1984. Effect of ratio of corn silage to grass-legume silage with high concentrate during dry period on milk production and health of dairy cows. J. Dairy Sci. 67:307-312.

McCormick, M. E., E. B. Morgan, T. F. Brown, and A. M. Saxton. 1990 Relationships between silage digestibility and milk production 
among Holstein cows. Page 60-64 in Proc. Forage and Grassland Conf., Am. Forage Grassland Council, Belleville, PA.

Montgomery, M. J., H. D. Baxter, and B. J. Bearden. 1976. Corn silage supplementation for maximum intake and milk production. J. Dairy Sci. 59:1915-1922.

National Research Council. 1989. Nutrient Requirements of Dairy Cattle. 6th rev. ed. Natl. Acad. Sci., Washington, DC.

Polan, C. E., C. N. Miller, and M. L. McGillard. 1976. Variable dietary protein and urea for intake and production in Holstein cows. J. Dairy Sci. 59:1910-1914.

SAS User's Guide: Statistics, Version 6 Edition. 1989. SAS Inst., Inc., Cary, NC.

Stern, M. D., H. Hoover, C. J. Sniffen, B. A. Crooker, and P. H. Knowlton. 1978. Effects of nonstructural carbohydrate, urea, and soluble protein levels on microbial protein synthesis in continuous culture of rumen contents. J. Anim. Sci. 47:944-956.

Van Vuuren, A. M., S. Tamminga, and R. S. Ketelaar. 1990. Ruminal availability of nitrogen and carbohydrates from fresh and preserved herbage in dairy cows. Neth. J. Agri. Sci. 38:499-512.
Van Vuuren, A. M., C. J. Can Der Kielen, H. Valk, and H. De Visser. 1993. Effects of partial replacement of ryegrass by low protein feeds on rumen fermentation and nitrogen loss by dairy cows. J. Dairy Sci. 76:2982-2993.

Van Soest, P. J., J. B. Robertson, and B. A. Lewis. 1991. Methods for dietary fiber, neutral detergent fiber, and nonstarch polysaccharides in relation to animal production. J. Dairy Sci. 74:3583-3597.

Waghorn, G. C., I. D. Shelton, and U. J. Thomas. 1989. Particle breakdown and rumen digestion of fresh ryegrass (Lolium perene L.) and lucerne (Medicago sativa L.) fed to cows during a restricted feeding period. Br. J. Nutr. 61:409-423.

Williams, C. C., M. A. Froetschel, L. O. Ely, and H. E. Amos. 1995. Effects of inoculation and wilting on the preservation and utilization of wheat forage. J. Dairy Sci. 78:1755-1765.

Wohlt, J. E., J. H. Clark, and F. S. Blaisdell. 1978. Nutritional value of urea versus preformed protein for ruminants. II. Nitrogen utilization by dairy cows fed corn based diets containing supplemental nitrogen from urea and/or soybean meal. J. Dairy Sci. 61:916-931. 